Pace University

DigitalCommons@Pace

$1-1-2001$

\title{
Criminal Prosecution for HMO Treatment Denial
}

John A. Humbach

Elisabeth Haub School of Law at Pace University

Follow this and additional works at: https://digitalcommons.pace.edu/lawfaculty

Part of the Criminal Law Commons, Health Law and Policy Commons, and the Medical Jurisprudence Commons

\section{Recommended Citation}

John A. Humbach, Criminal Prosecution for HMO Treatment Denial, 11 Health Matrix 147 (2001), http://digitalcommons.pace.edu/lawfaculty/88/.

This Article is brought to you for free and open access by the School of Law at DigitalCommons@Pace. It has been accepted for inclusion in Pace Law Faculty Publications by an authorized administrator of DigitalCommons@Pace. For more information, please contact dheller2@law.pace.edu. 


\title{
ARTICLES
}

\section{CRIMINAL PROSECUTION FOR HMO TREATMENT DENIAL}

\author{
John A. Humbach
}

A child is seriously ill. She will not live much longer if steps are not promptly taken. However, her parents' HMO has denied approval for the treatment that she needs. According to her doctor, the treatment has a good chance of helping. It could extend her life by months or even years. The treatment is, however, expensive, more than her parents can pay. Also, the initial cost is just the beginning. As long as the child lives she will need expensive care. It is a burden that the HMO does not want to take. So, a few days from now-maybe less-she will lapse into unconsciousness and, soon after, she will pass away. Her parents ponder this and think: "We've paid premiums to that HMO for years. If she dies now, because of this denial, somebody ought to pay; the law should make somebody pay for letting our daughter die."

\section{INTRODUCTION}

WEEN PEOPLE DELIBERATELY do things that are almost certain to cause death, and someone dies as a result, prosecutions for homicide are normally appropriate. However, the administrative conduct of health maintenance organizations (HMOs) seems to be an exception. Unwarranted delays and denials of medical treatment are not prosecuted even in cases where the HMO personnel must have known that their actions

† J.D. summa cum laude, Ohio State University (1966). Professor of Law, Pace University School of Law, White Plains, New York. 
would lead to death or grievous bodily harm. This article considers the basis for this exception.

Homicide can be committed by commission or by omission-by affirmatively doing a lethal act or by omitting to do an act that is necessary to preserve another's life. 'There is, however, an important legal difference between the two: In order for a fatal omission to be considered a crime, the omitter must have had a legal duty to act, ${ }^{2}$ and the victim's death must result from a breach of that duty. ${ }^{3}$ Such legal duties may arise in various ways. ${ }^{4}$ For example, a legal duty to provide care is imposed on the parents or legal guardian of a child. ${ }^{5}$ Such a legal duty may also be created by contract, for example when a person agrees to provide care for another. ${ }^{6}$ Consider the following case:

${ }^{1}$ See People v. Burden, 140 Cal. Rptr. 282, 289-92 (Ct. App. 1977); see also Commonwealth v. Hall, 78 N.E.2d 644, 647 (Mass. 1948); Territory v. Manton, 19 P. 387, 392-93 (Mont. 1888); Biddle v. Commonwealth, 141 S.E.2d 710, 714-15 (Va. 1965) (collecting numerous cases and treatises). See generally WAYNE R. LAFAVE \& AUSTIN W. SCOTT, JR., CRMINAL LAW 202-12 (2d ed. 1986); JOSHUA DRESSLER, UNDERSTANDING CRIMINAL LAW 89 (2d ed. 1995) (providing an overview of liability by omission).

${ }^{2}$ See, e.g., Jones v. United States, 308 F.2d 307, 311 (D.C. Cir. 1962) (requiring proof of the legal duty); Albright v. State, 280 So. 2d 186, 190-91 (Ala. Crim. App. 1973) (upholding demurrer to indictment that failed to allege the status relationship giving rise to the duty); People v. Oliver, 258 Cal. Rptr. 138, 142 (Ct. App. 1989) (noting that there is no legal duty to render aid in absence of a special relationship); see also MODEL PENAL CODE $\$ \$ 2.01(1)$, (3)(b) (Official Draft 1962) (commenting that "a duty to perform the omitted act is otherwise imposed by law").

${ }^{3}$ See DRESSLER, supra note 1, at 86-89; see also Pope v. State, 396 A.2d 1054 (Md. 1979); People v. Beardsley, 113 N.W. 1128, 1129 (Mich. 1907) (stating that "the duty neglected must be a legal duty, and not a mere moral obligation. It must be a duty imposed by law or by contract, and the omission to perform the duty must be the immediate and direct cause of death").

${ }^{4}$ See Jones, 308 F.2d at 310 (describing "at least four situations in which the failure to act may constitute breach of a legal duty," namely, a statutory duty of care, a status relationship to another, a contractual duty of care, and a voluntary assumption of care while secluding the victim); see also DRESSLER, supra note 1, at 89-91 (describing legal duties arising from statutory duty, status relationship, and contractual obligations).

${ }^{5}$ See, e.g., Jones, 308 F.2d at 310-11; People v. Burden, 140 Cal. Rptr. 282 (Ct. App. 1977) (sustaining a murder charge based on a parent's failure to feed an infant); People v. Abraham, 629 N.E.2d 148, 153-54 (111. App. Ct. 1993) (sustaining convictions for murder and aggravated battery based on parent's failure to take affirmative action to protect children from an abusive live-in boyfriend); Commonwealth v. Twitchell, 617 N.E.2d 609, 613 (Mass. 1993); State v. Norman, 808 P.2d 1159 (Wash. Ct. App. 1991) (upholding manslaughter conviction for parent who failed to perform legal duty to care for his son).

${ }^{6}$ See People v. Montecino, 152 P.2d 5, 13 (Cal. Dist. Ct. App. 1944) (finding that the legal duty to care for another may be created by contract or moral duty); Peo- 
D was the guardian of his young nephew. As such, D was responsible for the child's care. One day, $D$ heard his nephew fall in the bathtub. Running to check, $D$ found the child still alive, but face down in the water. It was obvious to $D$ that, unless he acted fast, the child would almost certainly drown. However, at this crucial moment, D recalled that he was his nephew's sole heir. With this financial thought in mind, $D$ did not take the actions that would probably have saved his nephew's life. As a result, the boy soon drowned. In summary, seeing a chance to gain a financial advantage at the expense of another's life, $D$ omitted to do an act that he had a legal duty to do and, by that omission, he hastened the death of the person to whom he owed the legal duty.

In deciding not to save his nephew, $D$ clearly committed a homicide by omission. ${ }^{7}$ He had a legal duty to act, he breached the duty, and the child died as a result. The uncle's motivation to gain a financial advantage is obviously not an acceptable excuse for letting his nephew die. Indeed, financial motivation seems, if anything, to aggravate the seriousness of his crime.

Suppose now that, trying to reduce its medical costs, an HMO breaches a legal duty to one of its subscribers. It breaches this duty by wrongfully denying treatment benefits that would, if timely provided, have preserved the subscriber's life; the subscriber dies as a result. How is such a case legally different from that of the uncle? Certainly there seem to be some salient similarities. In both cases, there has been a deliberate breach of a legal duty to provide essential care. In both cases, the lethal

ple v. Flayhart, 523 N.Y.S.2d 225 (App. Div.) (holding that guardians were guilty of criminal negligence for failing to care for the retarded brother decedent), affd, 553 N.E.2d 657 (1988); Commonwealth v. Pestinikas, 617 A.2d 1339, 1344 (Pa. Super. Ct. 1991) (holding defendant guilty of murder for agreeing to provide for a 92-year old and then letting him starve to death, knowing he had no other way to get food); Davis v. Commonwealth, 335 S.E.2d 375, 378 (Va. 1985) (holding that defendant accepted sole responsibility for the total care of her mother and that she had a legal duty to provide the care).

${ }^{3}$ See sources cited supra notes 1-6; see also Pinkerton v. State, 784 P.2d 671, 677 (Alaska Ct. App. 1989); People v. Stanciel, 606 N.E.2d 1201, 1211 (Ill. 1992) (noting that parents have an affirmative duty to protect their children from threat of murder and holding that neglect of this duty imposes liability by reason of accountability); State v. Wyatt, 482 S.E.2d 147, 153 (W.Va. 1996) (finding that "knowing failure to take reasonable steps" to prevent deprivation that resulted in a child's death constitutes murder). 
omission was inspired by a motive to secure a financial advantage, even at the expense of human life. In both cases, someone has died due to the breach of duty.

There may, of course, also be salient factual differences between the two cases. For example, medical patients who are so ill that they die from lack of treatment are often so close to death that they would soon die anyway, even with all possible care. By contrast, the case of the avaricious uncle seems to presuppose that the young nephew had a long life ahead of him, provided only that he was saved from drowning. This is, however, a difference without a legal distinction. Criminal liability for causing death is not relieved by the victim's pre-existing health condition, or the fact that the victim was going to die anyway. "Life at best is but of short duration" and, given the inevitability of eventual death, the law is clear that "[m]urder is never more than shortening of life," is, moreover, always a characteristic of omission-homicide cases that there are other causes of death than the omission alone. What makes fatal omissions into crimes is, precisely, the defendant's wrongful failure to avert such other causes.

The HMO case presents another potentially salient difference from that of the avaricious uncle. They differ in respect to the origin and scope of the legal duties in question. The HMO's duty is contractual and is subject to stipulated exceptions while the uncle's duty is rooted in a status relationship and is relatively unconditional. However, despite these differences in the origin and scope of the legal duty, once it is shown that the duty has in fact been breached, the cases would seem legally the same. That is, assuming the HMO breached its contractual duty by refusing to authorize timely care, the HMO and its decisionmaking personnel would seem to be in exactly the same legal position as the avaricious uncle-criminally liable for the death

${ }^{8}$ See People v. Morgan, 79 Cal. Rptr. 911, 913-14 (Ct. App. 1969) (holding appellant guilty of murder for causing the victim to die of a heart attack); State v. Malley, 366 P.2d 868, 873 (Mont. 1961) (allowing conviction if the "spark of life is extinguished by a wrongful act"); $c f$. Barber v. Superior Court, 195 Cal. Rptr. 484, 487 (Ct. App. 1983) (referring to superior court judge's conclusion that homicide is the shortening of life since everyone sooner or later will die).

${ }^{9}$ State v. Smith, 34 N.W. 597, 601-02 (Iowa 1887).

${ }^{10}$ People v. Phillips, 414 P.2d 353, 358 (Cal. 1966).

${ }^{11}$ See People v. Moan, 4 P.2d 545, 548 (Cal. 1884) (stating that it is homicide even if the victim has "a tenure upon life that cannot possibly continue for a day"). 
that results. ${ }^{12}$ Death-by-omission should be the same thing legally no matter who happens to be the omitter.

To my knowledge, no HMO entity or personnel have ever yet been criminally prosecuted for wrongful delay or denial of treatment authorization. It may, however, be only a matter of time before such prosecutions are attempted. Already there is a growing interest in civil actions for the harms that ensue when people, relying on HMOs, suffer or die because benefits are denied. ${ }^{13}$ There is, moreover, considerable disquiet about the federal limitations on HMO liability that were enacted by Congress in the Employee's Retirement Income Security Act (ERISA). ${ }^{14}$ However, the ERISA exemptions do not apply to criminal laws. ${ }^{15}$ In many cases, criminal prosecutions may therefore be the only effective avenues of redress.

In any case, criminal sanctions may actually work better than mere civil damages to motivate HMOs to authorize the medical treatments that their subscribers are contractually entitled to. One of the biggest disadvantages of allowing civil damages against HMOs is that the companies can simply shift the burdens of those "penalties" back to the subscribers, in the form of higher premiums. For the HMO, the amounts paid out as damages in lawsuits become just another cost of doing business. As a result, civil damages for wrongful treatment denials may actually work against the interests of the HMO's subscribers and patients, increasing premiums and diverting scarce resources away from medical care into judgments and lawyers'

${ }^{12}$ See infra Parts III and IV.

${ }^{13}$ For a prediction that "HMOs may replace big tobacco companies as the prime target of the nation's trial lawyers," see David G. Savage, Cost-Cutting Consequences: An HMO Liability Case is Being Closely Watched by the Lawyers Who Targeted Tobacco Companies, A.B.A. J., Feb. 2000, at 30. See also Chad Bowman, Special Report: Health Care Outlook 2000, 68 U.S.L.W. 2411, 2411-12 (2000) (observing that "the common law is evolving to allow patients to receive compensation for injuries caused by HMOs" and that "[1]iability protection for managed care continues to be the battleground for the coming year"); Richard A. Hinden \& Douglas L. Elden, Liability Issues for Managed Care Entities, 14 SETON HALL LEGIS. J. 1 (1990) (discussing potential liability for HMOs and PPOs with regard to provider selection and utilization management); Linda V. Tiano, The Legal Implications of HMO Cost Containment Measures, 14 SETON HALL LEGIS. J. 79 (1990) (describing liability theories that can arise when HMOs deny benefits causing patients' injury or death).

${ }^{14}$ See 29 U.S.C. \$ 1144(a) (1994) (stating that, with certain exceptions, laws relating to any employee benefit plan are superseded by ERISA).

${ }^{15}$ See 29 U.S.C. $\$ 1144(b)(4)$ (1994) (specifying that ERISA does not supersede "any generally applicable criminal law of a State"). 
fees. When people subscribe to HMOs, what they are primarily seeking is quality medical care, as needed, not a right to get cash "compensation" after the fact, when life-or-death treatments have been denied. ${ }^{16}$ Money is a poor recompense for a permanently impaired quality of life or the loss of life itself. It little serves the person denied benefits, or his surviving family and loved ones, to let an HMO get off with merely paying damages, which it can pass on to subscribers, instead of delivering the benefits it has promised in its contract. ${ }^{17}$

The legal agreements that people make with HMOs are no ordinary commercial contracts. The due performance of these agreements can be vital to life itself. As long as HMOs are able to shift the costs of their breaches, it may never be possible to minimize the number of wrongful HMO denials. The only way to prevent HMOs from shifting the penalties for wrongful denials is to impose a cost on wrongful denials that the HMO cannot shift. This is, of course, the classic function of the criminal law-to impose costs on bad behavior that offenders cannot shift. A civil defendant may shift the cost of a monetary judgment, but a criminal defendant cannot "shift" a prison sentence.

Although criminal punishment is a dramatic response to administrative errancy, the fact remains that it is the response prescribed by law for cases where people's conduct proves deadly or causes serious bodily harm. ${ }^{18}$ In the social debate about the role of HMOs, our nation's commitment to criminal punishment as a tool of social policy must be recognized as part of the background. In any case, the deterrent impact of criminal penalties can scarcely be doubted: A potential for criminal prosecutions would give HMO decision-makers a strong incentive to treat subscribers right, avoiding delays and unwarranted

16 "In choosing a health plan, consumers say that quality of care is their greatest concern ...." Report to Congressional Requesters, Consumer Health Care Information: Many Quality Commission Disclosure Recommendations Are Not Current Practice, GAO Rep. No. GAO/HEHS 98-137, at 18 (Apr. 30, 1998) (report of Bernice Steinhardt, Director, Health Serv. Quality \& Pub. Health Issues).

${ }_{17}$ As stated piquantly by Oliver Wendell Holmes, the idea "stinks in the nostrils" that a person who makes a promise need feel no compulsion to perform, provided the person is willing to pay legal damages. O. W. Holmes, Jr., The Path of the Law, in PHmosophy OF LAW 169, 171 (Joel Feinberg \& Hyman Gross eds., 5th ed. 1995).

18 Indeed, 38 states and the federal government currently prescribe the death penalty for lethal conduct under certain aggravating circumstances, such as when multiple victims occur. See State By State Death Penalty Information (visited Nov. 3 , 2000) <http://www.deathpenaltyinfo.org/firstpage.html> (Death Penalty Info. Ctr.). 
denials of treatment authorization. In addition, with prosecutions a possibility, the public could feel much more secure against wrongful medical care denials in any situation where the patient's life might be shortened or health seriously compromised.

In sum, while there are many possible approaches to the regulation of HMOs, ${ }^{19}$ the most straightforward approach may be simply to enforce the rules we already have, the existing rules of criminal law, the rules to which our society turns routinely to address a wide range of harmful activities. First, the criminal law has the advantage of subjecting wrongful treatment denials to a penalty that cannot be shifted back to subscribers. Second, the criminal law is not superseded by ERISA, so the current federal barriers to civil lawsuits would not stand in the way. Third, as will be described below, ${ }^{20}$ criminal prosecutions offer advantages with respect to proof. Medical decisions and judgments are necessarily discretionary, and it may be almost impossible for a civil plaintiff to demonstrate in an individual case that economic considerations played a role, much less an improper role, in an HMO's decision to deny benefits. ${ }^{21}$ In a criminal prosecution, by contrast, the needed evidence can be obtained by such well-tested prosecutorial techniques as, for example, offering leniency to subordinates in exchange for testimony against their superiors, the individuals directly responsible for forming HMO policies. Finally, as will also be outlined below, the criminal law on lethal and other injurious activities is rather clear. The only real questions seem to be factual. Did the HMO refuse to authorize treatment benefits in a situation where there was a legal duty to approve and provide them promptly? Were the HMO's decision-makers aware of the risks imposed

19 See John V. Jacobi, Canaries in the Coal Mine: The Chronically Ill in Managed Care, 9 HEALTH MATRIX 79, 106-26 (1999) (summarizing a variety of proposed and enacted regulatory measures). It is doubtful, however, that regulatory measures can have much effect since they are "always a step behind the latest business practice," while HMO cost containment methods "are simply too complex and subtle to be easily addressed by rigid regulations." Id. at 120 .

${ }^{20}$ See infra Part IV.C.

21 "Even in those few cases in which there have been legal claims [against HMOS], lawyers find that obtaining critical information from a plan is akin to getting gold bars out of Fort Knox." The Menace of Managed Care: A Guide to How Avoidance, Denial and Control Can Result in Patient Harm, Before the Subcomm. on Health \& Env't of the House Comm. on Commerce, 105th Cong. (Oct. 28, 1997) [hereinafter Menace of Managed Care] (prepared statement of Linda Peeno, M.D.), available in LEXIS ( Fed. News Serv.). 
on the patient? Was the patient's life shortened or health impaired as a result?

This article will, in Part II, first provide a brief examination of the economic pressures that market forces bring to bear on HMOs and their decision-making personnel. The objective is to show how the natural effect of normal market forces is to exert a constant pressure towards treatment delays and denials, particularly in the cases of elderly and chronically ill patients. Part III will provide an overview of the existing criminal law as it applies to situations in which death results because someone has violated a legal duty to provide medical treatment. In Part IV, the question of the requisite mental culpability will be discussed. Finally, after concluding that the criminal law provides, in its present state, a rather clear basis for homicide prosecutions of HMO personnel who authorize lethal treatment denials, a short Postscript will consider some further policy implications of HMO homicide prosecutions.

\section{THE PROBLEM OF "NET-NEGATIVE" PATIENTS}

In the past couple of decades, HMOs and other managed care firms have taken on a dominant role in the health care field, with for-profit HMOs now accounting for nearly twothirds of the total HMO market. ${ }^{22}$ Typically, these corporations have acquired the power to make essentially final decisions about who receives medical care, what kinds of care they receive, and when they can receive it. ${ }^{23}$ However, "[l]ike other

22 "Between 1985 and 1998 the proportion of HMO members enrolled in investor-owned plans increased from $26 \%$ to $62 \%$...." David U. Himmelstein et al., Quality of Care in Investor-Owned ws Not-for-Profit HMOs, 282 JAMA 159, 159 (1999). Half or more of privately insured Americans are enrolled in HMOs. See John E. Ware, Jr. et al., Differences in 4-Year Health Outcomes for Elderly and Poor, Chronically Ill Patients Treated in HMO and Fee-for-Service Systems, 276 JAMA 1039, 1039 (1996); see also William H. Nelson, Customers Demand Managed Care, HEALTHCARE FIN. MGMT., Aug. 1995, at 38 (stating that "about 66 percent of insured Americans are enrolled in HMOs and other forms of managed care plans"). "The defining feature of an HMO is receipt of a fixed fee for each patient enrolled under the terms of a contract to provide specified health care if needed." Pegram v. Herdrich, 530 U.S. 211, 120 S. Ct. 2143, 2149 (2000), discussed infra text accompanying notes 24-29.

${ }^{23}$ See, e.g., Dozsa v. Crum \& Forster Ins. Co., 716 F. Supp. 131, 134 (D. N.J. 1989) (noting that the Plan Administrator "retains ultimate authority to grant or withhold benefits"); Menace of Managed Care, supra note 21; Linda Peeno, Managed Care Ethics: The Close View (last modified May 30, 1996) 
risk-bearing organizations, HMOs take steps to control costs," and "[ $t]$ hese cost-controlling measures are commonly complemented by specific financial incentives to physicians, rewarding them for decreasing utilization of health-care services . . .."24 Indeed, as the Supreme Court recently recognized in Pegram $v$. Herdrich, "no HMO organization could survive without some incentive connecting physician reward with treatment rationing." 25 With this economic need for rationing in mind, ${ }^{26}$ the Court held that, under ERISA, ${ }^{27}$ HMO treatment decisions do not have to be made "solely in the interest of the participants and beneficiaries." 28

The obvious attraction of giving physicians incentives to refrain from prescribing treatments is that doing so cuts down the HMO's medical costs. As the Supreme Court observed, cutting down medical treatment costs does not necessarily increase medical risks-in fact, the Court noted, less treatment may sometimes even lead to less medical risk, for instance by cutting down the hazards of unnecessary surgery. ${ }^{29}$ However, unless our current levels of medical treatment are, on the whole, more risky than they are beneficial, it seems almost inevitable that less medical treatment will lead to more overall risk. This conclusion is, moreover, supported by some disturbing empirical evidence, which shows that rationing by HMOs may be increasing the medical risks to various classes of patients.

<http://www.harp.org/peeno.htm> (commenting that the HMO system claims the right to be the mechanism for the most serious of ethical decisions: determining who gets medical care).

${ }^{24}$ Pegram, 120 S. Ct. at 2149.

${ }^{25}$ Id. at 2150.

${ }^{26}$ An additional concern was to avoid a judicial "upheaval." Id. at 2156.

${ }^{27}$ See 29 U.S.C. \$ 1104(a)(1) (1994); see Pegram, 120 S. Ct. at 2155-59 (explaining conclusion that HMOs are not acting as fiduciaries).

${ }^{2 x}$ Pegram, 120 S. Ct. at 2151 (quoting 29 U.S.C. \$ 1104(a)(1) (1994)). The Court reached this conclusion by reasoning that HMO treatment decisions are not "fiduciary acts," as that term is used in ERISA. See id. at 2152, 2157-58. If treatment decisions were considered to be fiduciary acts subject to ERISA, then the applicable standard for HMO treatment denials would be as defined in 29 U.S.C. $\$ 1104(a)(1)$. Notwithstanding the Court's holding in Pegram, the physician-employee's decisions would still, of course, be subject to ordinary medical malpractice standards, which would continue to apply under state law. See id. at 1257-58. Ultimately, then, what Pegram denies is that an injured patient has "a further defendant to be sued" in a federal ERISA action brought directly against the HMO, which "might have a deeper pocket than the physician." Id. at 2158.

${ }^{29}$ See id. at 2150. 
For example, in the fall of 1996, the Journal of the American Medical Association (JAMA) reported an extensive study of the medical outcomes for patients who had been treated in HMOs. ${ }^{30}$ The study concluded that "elderly and poor chronically ill patients had worse physical health outcomes in HMOs" than under traditional insurance plans. ${ }^{31}$ For example, "[t]he elderly treated in HMOs were nearly twice as likely to decline in physical health over time." 32 By contrast, younger, healthier, and financially better-off patients "did at least as well in HMOs as in the [fee-for-service] plans." 33 Other studies have generally confirmed these results: While HMOs serve the "average, healthy enrollee" about as well as traditional health insurance, they usually appear to provide "worse outcomes . . . for vulnerable groups (i.e., the seriously ill, the mentally ill, and the poor)." ${ }^{34}$ For anyone familiar with the elementary laws of economics, this difference in medical outcomes should come as no surprise.

First, consider the context. Most large HMOs are publicly traded on national stock exchanges and, as such, their securities are in daily competition with those of other corporations. Their financial results are closely scrutinized and compared, by Wall Street analysts and others. This public market activity means that HMO executives are under steady pressure to keep medical

${ }^{30}$ See Ware, Jr. et al., supra note 22 , at 1042-47.

31 Id. at 1039.

${ }^{32} \mathrm{Id}$. at 1044 .

${ }^{33} \mathrm{Id}$. at 1046. In traditional or "fee-for-service" insurance plans, the insurance carrier pays or reimburses for treatments ordered by the patient's doctor or health care provider, but does not directly take a role in selecting providers or deciding on treatments. See Pegram, 120 S. Ct. at 2148-49 (explaining operation of traditional fee-forservice medical care). As the Court explained the crucial economic difference between HMOs and fee-for-service plans: 'In a fee-for-service system, a physician's financial incentive is to provide more care, not less, so long as payment is forthcoming ... in an HMO system, a physician's financial interest lies in providing less care, not more." Id. at 2149. In both systems, the "check" on these financial self-interest influences is the physician's professional obligation to act with "reasonable medical skill and judgment in the patient's interest." Id. In both, too, the adequacy of the physician's professional obligation to counter the economic influences "has been challenged." Id.

${ }^{34}$ Himmelstein et al., supra note 22, at 159 (citing prior research where worse outcomes appeared in eight out of 10 studies). The unfavorable comparisons that emerge from studies such as these have apparently spurred HMOs into action. According to Himmelstein et al., more and more plans are refusing to release the data on which such studies are based. See id. at 163 (noting that 41 plans refused to release data in 1997 while 155 plans retused in 1998). 
costs down and profits up. Otherwise, the price of the HMO's stock will fall and the jobs of its managers will be in jeopardy. When compensation packages are tied to profits or include stock options in the HMO's securities, the decision- makers have an even greater personal interest in the financial success of their companies and their market valuations. The market does not reward them for saving lives at stockholder expense. ${ }^{35}$

Looking at the world through the eyes of a rational HMO executive, the company's clientele can be divided into two groups: First, there are the subscribers who will probably pay more in future premiums than they will cost the HMO in future medical services." This is the "net-positive" clientele. The other group is "net-negative." It contains the subscribers who will probably cost more in future medical services than they will ever pay in future premiums. Members of the net-negative group include the most seriously ill, those who have only a small chance of recovery, as well as the chronically ill people whose diseases are both lingering and expensive to treat. The "net-negatives" are perhaps typically, though not always, elderly. Young or old, however, they are the subscribers whose medical prognoses make it improbable that they will ever be anything but unprofitable business for the HMO, a net financial drain on its bottom line for the rest of their lives. They are not the kind of customers that a rational HMO manager would normally want to have.

By tallying up and correlating the medical diagnoses, prognoses, treatments, and outcomes of the HMO's subscribers, the actuarial staff of an HMO can make fairly reliable estimates of who does and does not fall in the "net-negative" group. Then, whenever a subscriber requests approval for expensive treatments, the HMO's medical-review staff can check the subscriber's file and make a straightforward monetary calculation. If the calculation shows that the subscriber will probably turn out to be "net-positive," then it is in the HMO's economic interest to promptly approve payment for the requested medical treatment. This will keep the subscriber happy and, so, the HMO will more likely retain the subscriber's business. Given

35 As one commentator has stated: "[T] he financing system at the heart of managed care is at war with its care-giving potential when it comes to the chronically ill." Jacobi, supra note 19, at 107.

${ }^{36}$ All future amounts being appropriately discounted to present value to account for the "time-value of money." 
normal economic incentives, it is no surprise that the JAMA study reported that younger, healthier people generally did well under HMO systems. ${ }^{37}$

The matter is, however, entirely different in cases where the HMO's prognosis-based calculations would show that the subscriber will probably turn out to be "net-negative." It would not be at all in the HMO's economic interest to extend the lives of net-negative patients. That would just prolong a losing proposition. The financial problem for the HMO is far greater than merely being unable to recoup the immediate out-of-pocket treatment costs. For many serious diseases, such as certain forms of cancer, prompt and comprehensive treatment can prolong the patient's life very substantially. If timely diagnosis and treatment extends an ailing patient's life by, say, five years, those five years might mean additional millions of dollars in treatment costs to be borne by the HMO. Consequently, when an HMO gives prompt and comprehensive treatment to the chronically ill, it risks taking on a stream of financial costs that can go on indefinitely. In terms of HMO economics, this can mean a tremendous increase in the lifetime cost of a subscriber who is already a net drain on the HMO's finances. The economic incentive to avoid aggressive diagnosis and time-critical treatments of certain kinds of ailments is therefore obvious.

Economically rational HMO managers know that their company's stock price depends on the bottom line. They know that every dollar spent on a net-negative patient is one less reason why the HMO's securities should command their current prices on the national stock exchange. With jobs and personal wealth ultimately on the line, the economically rational HMO manager can hardly help wondering how to minimize, somehow, the financial burdens posed by the HMO's net-negative subscribers. The chief financial question that they present for the HMO is: How long?

What particularly exacerbates this somber economic reality is the fact that medical decisions are necessarily discretionary and never exact. Medical professionals can, in complete good faith, differ substantially as to what therapies are called for or

${ }^{37}$ See Ware, Jr. et al., supra note 22 , at $1042-47$, discussed supra at text accompanying notes 33-34. 
necessary in a particular case. ${ }^{38}$ When this intrinsic indefiniteness is combined with the pressures to minimize the netnegative clientele, a potent and scary synergy can emerge. Especially in cases of serious illness, there are ample leeways within which to conceal an economic biasing or tilt against an HMO's net-negative subscribers. It is not so easy for an objective outsider to say with confidence that a given delay or denial was motivated by financial, as opposed to medical, considerations. Adding to the cover is the fact that only a relatively small delay in testing or treatment can make a life-or-death difference in a medical outcome. ${ }^{39}$ If a company implements its costcontainment measures by means of subtle signals and hidden incentives within the plan, a deliberate policy to selectively delay or deny benefits would not necessarily be obvious to persons familiar only with one or a few isolated treatment decisions. In short, a quiet and low-key bias against treatment authorizations to the net-negative clientele would be relatively hard to detect medically, but it could have a very buoyant effect on the company's bottom line. This is a tempting combination.

Even though treatment biases might be difficult to detect in isolation, however, they would tend to be felt in the aggregate, showing up for example in comprehensive surveys such as the

${ }^{38}$ According to one of the principal authors of the annual Dartmouth Atlas of Health Care, "there is no national consensus about the 'best practice' of medicine" and "little systematic evaluation of the relationship between medical services and health outcomes." Medical Necessity: From Theory to Practice, Before the Senate Comm. on Health, Educ., Labor \& Pensions, 106 Cong. (Mar. 2, 1999) (prepared testimony of John E. Wennberg, Director, The Center for the Evaluative Clinical Sciences, Dartmouth College), available in LEXIS (Fed. News Serv.). The "failure to evaluate the outcomes of care means substantial disagreement and controversies exist concerning what actually works." Medicare: Its Context and Evolution, Hearings Before the Senate Finance Comm., 106 $6^{\text {th }}$ Cong. 1999 (testimony of John E. Wennberg, M.D., M.P.H.), available in LEXIS (Fed. News Serv.). The Dartmouth Atlas shows that, "on a per-enrollee basis, spending varies substantially among regions in the United States, even after adjustment for differences in illness and price." Id. However, "[t]he results challenge the view that regions with higher levels of per capita spending provide higher quality care. Indeed, the opposite may be the case." Id. "[M]ore Medicare spending does not translate into longer, or better, life." Id.

${ }^{39}$ See, e.g., Shea v. Esensten, 107 F.3d 625, 626 (8th Cir. 1997) (involving a patient with "warning signs" who died of an undiagnosed heart condition a few months after his $\mathrm{HMO}$ physician, who had a financial incentive to minimize referrals, declined to refer him to a specialist); see also Pegram, 120 S. Ct. at 2147 (describing how patient suffered a burst appendix and peritonitis, a life-threatening ailment, due to an 8-day delay in testing an abdominal mass); Dozsa v. Crum \& Forster Ins. Co., 716 F. Supp. 131, 133 (D. N.J. 1989) (noting that "time was of the essence with respect to the treatment"). 
JAMA-reported research referred to earlier. ${ }^{40}$ The inferior medical outcomes registered by elderly and poor chronically ill patients in HMOs might be entirely a matter of coincidence, with no relation to the market incentives that surround HMOs, or they may be a result of deliberate policy choices. Whether or not intentional, however, the effect is the same. It is an effect that coincides exactly with the sort of decision bias that would well serve an HMO that is trying to cut its losses from netnegative patients. Assuming that HMO managers behave in an economically rational way, such a bias with respect to the elderly and chronically ill would be a normal and expected effect of ordinary market forces and incentives.

In some ways these economic realities faced by HMOs are similar to those that apply to traditional "fee for service" insurance, but HMOs are in a particularly strong position to deal with these realities. Under fee-for-service plans, the insurance company is more at the mercy of the patient's own doctor or health care provider. The doctor or provider makes the treatment decisions, and the insurance company pretty much has to pay for whatever treatments are ordered. Even with a growing tendency towards enhanced utilization reviews and other costcontainment measures in the fee-for-service sector, the fact remains that a fee-for-service insurer leaves health care providers with far more independence and subjects them to much less direct pressure to keep treatment costs down. In fee-for-service it is the doctor's own professional judgment that generally controls medical decisions, not the insurance company's.

By contrast, it is both the genius and the great weakness of HMO-type managed care that final treatment decisions are reserved to the ones paying the bills. Its strength is that it keeps the costs down, but its weakness is that it eliminates the checks that are inherent in the old and arguably less "efficient" fee-forservice system. "[I]nducement to ration care goes to the very

${ }^{40}$ See Ware, Jr. et al., supra note 22 , at $1042-47$, and text accompanying notes 22-23 \& 30-34.

41 "Each method [HMOs and fee-for-service] creates an unfortunate incentive: a physician receiving a fee for each service has an incentive to run up the bill by furnishing unnecessary care, and an HMO has an incentive to skimp on care (once patients have signed up and paid) in order to save costs." Herdrich v. Pegram, 170 F.3d 683, 684 (7th Cir. 1999) (Easterbrook, C.J., dissenting), rev'd, 530 U.S. 211, 120 S. Ct. 1243 (2000). See also supra text accompanying notes 32-33; Jacobi, supra note 19 , at $97,103-05$ (describing how and why HMOs are institutionally predisposed to engage in "stinting," i.e., denying patients medially appropriate care). 
point of any HMO scheme"42 and, as doctors and other health care providers come to depend more and more on HMOs for their own personal livelihoods, they will naturally feel stronger economic disincentives to press for medical tests and treatments. ${ }^{43}$

By resort to various techniques, such as "economic credentialing" of physicians, secret bonuses to deter expensive treatments, ${ }^{4+}$ utilization "profiling" and "capitation" (paying doctors a set annual amount per patient), HMOs have proven quite adept at keeping the most important decisions about treatment expenditures to themselves. ${ }^{45}$ This is fine for those subscribers who are generally in good health and thus likely to be a future profit source, so the HMO will want to keep them happy. It is, however, not so fine for the patient who needs a time-critical medical treatment but whose HMO would be financially better off if the patient were already deceased.

To state the problem bluntly, there is a potentially lethal economic flaw in the HMO concept. The flaw is that the final say on whether a person gets life-extending treatment is consigned to an entity that can have a strong economic interest in seeing the subscriber dead, as soon as possible. The shorter the lives of the chronically ill, the less the HMO will have to pay for their care. No one would think it fair to hold trials before judges who have personal financial stakes in the outcomes. Yet, this is precisely the way that the HMO concept is structured. That is, arguably at least, a very serious flaw. ${ }^{46}$

$\$ 2$ Pegram, 120 S. Ct. at 2150.

${ }^{43}$ See generally Menace of Managed Care, supra note 21.

+4 See Shea v. Esensten, 107 F.3d 625 (8th Cir. 1997) (holding that HMO breached its fiduciary duty by not disclosing its use of "financial incentives that were designed to minimize referrals" to specialists). See generally Edward B. Hirshfeld, Should Third Party Payors of Health Care Services Disclose Cost Control Mechanisms to Potential Beneficiaries? 14 SETON HALL LEGIS. J. 115 (1990) (concluding that HMOs should disclose).

45 See Hirshfeld, supra note 44, at 117-18. Lamented the attorney, representing the patient in Pegram v. Herdrich, 530 U.S. 211, 120 S. Ct. 2143 (2000), doctors "can receive an annual bonus for not ordering diagnostic tests." Savage, supra note 13, at 30. His client had suffered a burst appendix and life-threatening peritonitis due to a misdiagnosis and an 8-day delay in testing an abdominal mass. See id.; see also Pegram, 120 S. Ct. at 1247.

${ }^{16}$ See Jacobi, supra note 19, at 131-37 (suggesting partial capitation and other "mixed" systems, that use managed care-based cost containment incentives along with fee-for-service provisions, for cases of especially expensive treatment needs). 
It can be equally argued, to be sure, that this feature in the HMO concept is not a flaw at all. The recent growth of HMOs is apparently due in major part to the hope that they can provide health care services at less societal expense. A key part of their strategy for doing this is that they combine the roles of decision maker and bill payer, which gives the HMO both the incentive and the ability to say "no" to expensive medical treatment. In purely economic terms, this represents the great advance of HMOs over the old fee-for-service system. A disproportionate share of national medical spending goes for people in their last few months of life, a substantial skewing of resources to people who are about to die anyway. ${ }^{47}$ The HMOs' enhanced ability to say "no" to costly life extension is perhaps (depending on your viewpoint) the biggest service that they provide to society. By being systematically disposed to say "no" more often, HMOs have the ability to keep down the insurance premiums of healthy people while, at worst, shortening lives of those already near death. If you do not mind looking at things this way, then HMOs are the way to go.

Actually, I believe that, to date at least, most HMO managers would not look at things in this way. ${ }^{48}$ What saves us from these hard economic imperatives may be something that feminist psychologist Carol Gilligan has called the "awesome power

${ }^{47}$ A study in the New England Journal of Medicine reported that roughly 30\% of Medicare expenditures were spent on patients in the last year of life, with the final 60 days accounting for about one-half of that final year's spending and the last 30 days accounting for about $40 \%$. See James D. Lubitz \& Gerald F. Riley, Trends in Medicare Payments in the Last Year of Life, 328 NEw ENG. J. MED. 1092, 1092-95 (1993). These figures remained "virtually the same from 1976 through 1988." Id. at 1094; see also Richard A. Knox, Care at End Not as Costly as Assumed, BostoN GloBE, Apr. 15, 1993, at 1. These figures for Medicare coverage, however, do not include most of the cost of nursing home care, which is "an important service for the elderly," and therefore probably understate significantly the total medical costs incurred in the last months of life. Lubitz \& Riley, supra, at 1095. The 31\% of Medicare spending would translate to about $10-12 \%$ of total national health care spending occurring the last 12 months of life.

${ }^{48}$ For a vigorously argued and less sanguine view of the current state of HMO care, see Menace of Managed Care, supra note 21. See also the less sanguine view of Dr. David Himmelstein, a principal author of one of the HMO performance studies referred to in supra note 22 , who reportedly stated, after an HMO industry spokeswoman accused him of "confusing "analysis and ideology", "[m]y bias is that forprofit H.M.O.'s kill people," quoted in Sheryl Gay Stolberg, Report Say ProfitMaking Health Plans Damage Care, N.Y. TIMES, July 14, 1999, at A18. 
of the irrational." "' Because of this "awesome power," the assumptions of economic rationality made by classical economics are overstated caricatures; they do not reflect actual human behavior in situations where powerful non-rational concerns also come into play. For example, most people probably place a very considerable value on not being killers, even if they can get away with it, or on not doing things that shorten others' lives, even when the countervailing economic incentives are great. ${ }^{50}$

To the extent that Gilligan's "awesome power" prevails, we may expect that HMO managers will be exceptionally able to resist the strong economic incentives that they have to quickly cut losses when subscribers turn net-negative. The problem is, however, that this exceptional and "irrational" resistance to cutting the company's losses may gradually erode over time. Even the most conscientious HMO management will not last very long if it does not keep the costs down, the revenues up, and the premium rates in line with those of their competitors. They are ineluctably bound to respond "rationally" to normal market

${ }^{49}$ Carol Gilligan, Preface to Mapping the Moral Domain: A ContRibution OF WOMEN'S THINKING TO PSYCHOLOGICAL THEORY AND EDUCATION Xvi (Carol Gilligan et al. eds., 1988).

S. Actually, it is arguable whether conduct is properly termed "irrational" when people act on non-economic values such as those mentioned in the text. See Richard S. Lazarus \& Bernice N. Lazarus, Passion and REASON: MAKING SENSE OF OUR EMOTIONS 203-08 (1994). While some behavior may seem irrational when compared with what an economically rational person would do, from a different perspective the same behavior might be seen as perfectly rational. The reason for the apparent discrepancy is that economic values are only a subset of all human values and, therefore, economic rationality is only a subset of total rationality.

From the larger perspective, the main origin of economically irrational behavior (other than pure misjudgment or inadvertence) is the fact that economic values and objectives are not, for most people, ends in themselves but only means to other ends, other values that people are motivated to pursue in life. Because economic resources are crucial to obtaining many of the most important things in life-food, shelter, sexual partners, esteem, etc.-economic values generally provide a convenient proxy for the things that people are really seeking in market transactions. For this reason, the economists' postulate that people act rationally to pursue economic values is a very convenient simplifying assumption about human behavior, one that works well for many analytical purposes and allows the creation of robust behavioral models to compare otherwise incommensurable values.

However, like all simplifying assumptions, this economic assumption can generate models that produce significant discrepancies from real life in some cases. For example, the value most people place on not being killers, discussed in the text, may produce seriously "irrational" economic behavior. It can cause people to deviate from model-predicted behavior because it is a value that is not, in many contexts, readily commutable to the economic proxies (dollars) that economic theory otherwise uses so deftly and successfully to compare incommensurables. 
pressures or else risk being replaced by people who will. Market discipline is not sentimental and, if the tenets of free market economics are valid, the only HMOs that will survive in the longer run will be those whose managements behave like economically rational decision-makers. As competitors seek advantage through moral slippage on the question of serving the net-negatives, economic pressures to meet the competition will fall on everyone else, as well.

In any case, if one of the very purposes of HMOs is to reduce the overall costs of health care, to prevent the "waste" of health care dollars, then at least some treatment decisions will have to be based, at least partly, on dollars and cents calculations; it will not be possible to keep medical need and financial considerations entirely separate, even in principle. Moreover, as the economic circumstances of their companies become tighter in the face of competitive winnowing, HMO managers may find themselves ever less at liberty to make hard economic sacrifices in order to extend human life. In short, it would be naive to assume that the HMO industry can remain satisfactorily immune to the normal laws of economics that drive our free market economy in general, and make it so strong. As long as HMOs are run by self-interested rational individuals, these economic pressures must somehow eventually be felt.

In making public policy, the normal market forces to which HMOs are subject cannot be ignored. What the existence of these forces suggests is this: The position of conscientious HMO managers is not unlike the position of manufacturers in "dirty" industries who want to stop polluting but cannot unilaterally make anti-pollution expenditures without giving their competitors a crucial cost advantage. In these situations, the enforcement of anti-pollution laws is the way that we level the playing field, so that those who want to do the right thing can, and those who do not, will. Just as a manufacturer may need anti-pollution laws to remain competitive while doing the right thing, the conscientious HMO manager also needs the enforcement of laws, such as laws against homicide, to prevent less scrupulous rivals from gaining a competitive advantage by inappropriately mixing up questions of medical necessity with issues of pure economics.

To conclude, if the usual assumptions underlying the free market system hold true, then HMOs are under constant economic pressure to curtail the net cash drain they face every time 
one of their subscribers goes "net-negative." Even with the best of intentions, an HMO simply cannot, in a competitive market, lavish its assets on net-negative subscribers if its competitors are not doing likewise. Because economically-biased deferrals or denials of treatment would not always be easy to detect, it seems logical to attach the most serious of consequences to those that are. Homicide is a category of crime that applies when people behave in ways that shorten the lives of others. When a patient's life is shortened by a wrongful refusal to authorize medical treatment, the offense of homicide is legally indicated.

\section{VIOLATING THE DUTY TO PROVIDE MEDICAL CARE}

It certainly seems morally questionable for health insurers to deny coverage for life-saving medical treatments just because they cost "too" much. But can a wrongful denial of treatment on economic grounds be a crime as well? If it is a crime, moreover, whose crime is it?

The discussion in the remainder of this article will focus on the possible criminal liability of HMO personnel who, in the course of their jobs, make decisions to deny medical treatment authorizations and foreseeably hasten the deaths of persons who depend on HMOs for treatment. The goal is to provide an outline of the basis on which prosecutions could be legally warranted by the already existing, generally accepted framework of criminal law.

From the standpoint of the HMO, a failure to authorize lifesustaining care to a person who needs it is an "omission," a mere omission is not a crime unless there is a legal duty to act. ${ }^{52}$ However, by virtue of their contracts with their subscribers, HMOs do have a legal duty to act; they have a legal duty to authorize and provide payments for certain medical care-not any and all prescribed care, perhaps, but at least some medical care. It is therefore a crucial threshold question: What are the scope of and limits on an HMO's legal duty to provide medical care, especially in life-threatening situations?

52 See supra notes 2-6 and accompanying text. 


\section{A. Outer Limits of the Duty}

A leading case on a physician's duty to provide medical services to patients in life-or-death situations is Barber v. Superior Court. ${ }^{53}$ Compared with the physician's duties, an HMO's duties may be markedly less extensive since they can presumably be limited and tailored in the subscriber agreement. ${ }^{54} \mathrm{Nev}-$ ertheless, the Barber case is of interest; it would seem to supply the outer limits of the HMO's potential duty.

The patient in Barber was a man who had suffered a cardio-respiratory arrest a short time after undergoing an abdominal surgery. ${ }^{55} \mathrm{He}$ was revived and placed on a life support system. ${ }^{56}$ Three days later he was still deeply comatose, a state from which he was "not likely" to recover ${ }^{57}$ Tests and examinations by specialists indicated that he had suffered severe brain damage. ${ }^{58}$ Although not "brain dead," 59 he was in a vegetative state that was deemed "likely" to be permanent. ${ }^{60}$ After consultation with the patient's family, and on their instructions, the doctors in charge "caused the respirator and other lifesustaining equipment to be removed."61 Two days later, they removed the intravenous tubes that provided hydration and nourishment. ${ }^{62}$ The patient died.

The question in Barber was whether the doctors could be properly charged with murder and conspiracy to commit murder. ${ }^{63}$ The lower court concluded as a matter of law that the doctors' conduct, "however well motivated" and ethically "sound" as a medical matter, was unlawful under California law. ${ }^{64}$ Observing that homicide means simply the "shortening of life by some measurable period of time," the lower court judge

53195 Cal. Rptr. 484 (Ct. App. 1983). The case is the subject of an annotation, see Gregory G. Sarno, Annotation, Homicide: Physician's Withdrawal of Life Supports from Comatose Patient, 47 A.L.R. 4th 18 (1986).

${ }^{54}$ See infra Part III.C.

55 Barber, 195 Cal. Rptr. at 486.

${ }^{56}$ See id.

57 Id.

${ }^{58}$ See id.

${ }^{59} I d$. at 488 .

${ }^{60} I d$. at 486.

${ }^{61} \mathrm{Id}$.

${ }^{62}$ See id.

${ }^{63}$ See id. (citing CAL. PEN. CODE $\$ 187$ and $\S 182$, respectively).

${ }^{64}$ Id. at 487 (rejecting the conclusion of the magistrate). 
held that the doctors' intentional acts to remove the biological necessities for life constituted murder. ${ }^{65}$

The doctors could not, of course, legally claim to excuse their actions merely on the ground that their motives were good or beneficent. As the appellate court stated in Barber, "the law is settled that motive is irrelevant to a determination of whether a killing amounts to murder...." ${ }^{66}$ Nor did the circumstances of the case bring it within any of the recognized categories of "excuse" or "justification." "67 "Euthanasia," said the court, "is neither justifiable nor excusable in California." ${ }^{68}$ Although the appellate court was evidently concerned about the "gap between the statutory law and recent medical developments,"69 it nonetheless felt constrained to decide the case according to the "existing criminal law." interest here.

On the basis of its analysis of the existing law, the appellate court in Barber ordered the criminal proceedings against the doctors to be terminated. ${ }^{71}$ It held that the doctors did not, on the facts of the case, have any further legal duty to provide medical care to the patient at the time when the life-support was removed. ${ }^{72}$ The general rule is, according to the appellate court: "A physician has no duty to continue treatment, once it has proved to be ineffective." 73 With particular reference to lifesustaining machinery, it said that "there is no duty to continue its use once it has become futile in the opinion of qualified medical personnel." ${ }^{.74}$ These conceptual limits on the doctor's duty, "futile" and "ineffective," are both obvious and minimal. A duty to help another cannot logically be breached once the other is beyond help anyway. The Barber doctors did no wrong by merely omitting to do things that would have served no purpose at all.

The matter is not, however, quite so simple. For one thing, biological uncertainty being what it is, the concepts of "ineffec-

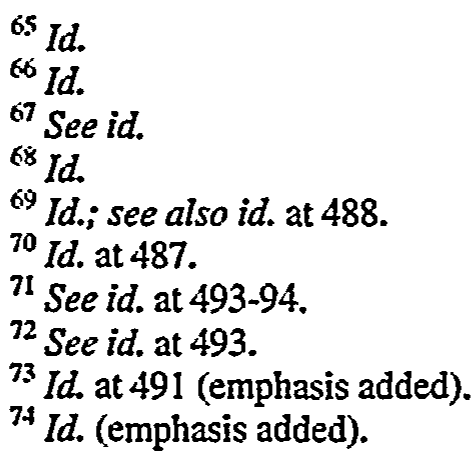


tive" and "futile" are necessarily somewhat relative. As long as basic physiological processes continue, revival remains a possibility. Recently, an elementary school principal returned to work two weeks after hospital doctors had declared him dead. ${ }^{75}$ A woman regained consciousness and was munching pizza after 16 years in a coma. ${ }^{76}$ Adding even further to these biological uncertainties, the court in Barber seemed to define "futility" to mean less than literal futility. The test, according to the court, was whether further treatment would offer "reasonable benefit to the patient."77

For this purpose, the court invoked a sort of proportionality analysis, whether the proposed treatment "has at least a reasonable chance of providing benefits to the patient, which benefits outweigh the burdens attendant to the treatment." 78 Thus, for example, even "minimally painful or intrusive" procedures may be unwarranted where "the prognosis is virtually hopeless for any significant improvement." 79 Notably, however, the court did not appear to think that burdens to persons other than the patient, such as burdens to the doctors or medical payors, had any proper role in the determination. Only burdens to the actual patient, such as pain, were mentioned as proper considerations.

Where continuing medical treatment is of only "debatable value," 80 the really crucial question may be: Who decides? Whose job is it to weigh, with fatal finality, the benefits and burdens of treatment to the patient? On this question, the Barber court stressed the primacy of patient autonomy: "[W] henever possible, the patient himself should . . . be the ultimate decision-maker." 81 Otherwise, the decision should be

75 See Steve Shoup, Man Breathes After 'Death' at Hospital, AlBUQUERQuE J., Oct. 21, 1999, at A1; Scott Smallwood, Life 'as Usual' Precious Gift for Principal, AlBUQUERQUE J., Nov. 2, 1999, at Cl.

${ }^{76}$ See Ben Fenton, Woman in Coma for 16 Years Meets Her Children, DAlly TELEGRAPH (London), Jan. 6, 2000, at 5; James Langton, The Day that a Sleeping Beauty Woke Up, SuNDAY TELEGRAPH (London), Jan. 9, 2000, at 24; see also Adam Gershenson, Tender Care, Courage and Top-Notch Grades, N.Y. TIMES, Jan. 28, 1999 , at B4 (noting that a woman returned to college after being declared dead twice).

${ }^{7}$ Barber, 195 Cal. Rptr. at 491 (emphasis added).

${ }^{78}$ Id.

${ }^{79} I d$. In these extreme cases, even a treatment course that is "only minimally painful or intrusive" may be considered disproportionate. Id.

${ }^{80} \mathrm{Id}$. at 492.

${ }^{81} \mathrm{Id}$. 
given to a person who would be "guided in his decision by the patient's best interests." 82

At one point the court appears to accept the view that the doctors themselves might be authorized to determine the limits on their own legal duties. ${ }^{83}$ However, the court also relayed the worry that physicians' decisions may not always be free "from possible contamination by self-interest or self-protection concerns which would inhibit their independent medical judgment for the well-being of their dying patients." ${ }^{\text {"I }}$ In the end, the court states that a doctor's duty to provide treatment continues until the "patient himself," or, at least, a surrogate preoccupied with the patient's own interests, decides that further treatment is futile. ${ }^{85}$ Nowhere did the Barber court suggest that economic interests of the duty-holder are legitimate factors in determining whether a patient should receive life saving medical care. ${ }^{86}$

The relatively few other cases that comment on a medical provider's legal duty to render care in end-of-life contexts generally accord with Barber in stressing the patient's interests as controlling. ${ }^{87}$ Although doctors and patients presumably have the freedom of contract to make different arrangements, the Barber case appears to represent, in general, the terms of the "contract that the law implies" between doctor and patient.

${ }^{2}$ Id. at 493.

${ }^{83}$ See id. at 491. "A physician is authorized under the standards of medical practice to discontinue a form of therapy which in his medical judgment is useless...." Id. (quoting Dennis Horan, Euthanasia and Brain Death: Ethical and Legal Consideration, 315 ANNALS N.Y. ACAD. SCI. 363, 367 (1978)).

${ }^{*}$ Barber, 195 Cal. Rptr. at 491 (quoting Matter of Quinlan, 355 A.2d 647, $668(1976))$.

${ }^{85}$ See id. at 492.

${ }^{86}$ It should be noted how stark is the contrast between the stress on the patient's autonomy in Barber and the practice in the HMO context where, by design, the patient turns over crucial treatment decisions to the HMO's personnel, whose loyalties can be distinctly mixed and whose explicit goals can include reduction of "utilization" and the "containment" of medical costs. See id. and cf. Doe v. Group Hospitalization \& Med. Serv., 3 F.3d 80 (4th Cir. 1993) (relying on Firestone Tire \& Rubber Co. v. Bruch, 489 U.S. 101, 110-15 (1989), and recognizing that ERISA allows medical plan fiduciaries to have conflicts of interest in which they might be required to choose between the patient or the plan, but holding that where such conflicts of interest exist a court reviewing denials of coverage should give less deference than would otherwise be appropriate).

${ }^{87}$ See Sarno, supra note 53, at 18 (collecting and summarizing these cases). 


\section{B. Denying Medical Care: Omission or Act?}

One of the most striking aspects of the analysis in Barber is the way the court got itself to the question of whether the doctors had a duty to continue treating their dying patient. The court said that disconnecting the patient's vital life support was only an "omission," not an affirmative act. ${ }^{88}$ This was a crucial logical step: If the doctor's had done an "act" in disconnecting the life support, they would almost certainly have violated the law; everybody has a duty to refrain from doing acts to end another's life. However, by holding the removal of the life support to be an omission rather than an act, the court opened the door to exonerating the doctors from the murder charges. For once the conduct was held to be an omission the court was able to invoke the "no duty, no guilt" analysis, already described. ${ }^{89} \mathrm{It}$ could exonerate the doctors by a finding that, given the patient's extreme condition, the doctors no longer had a duty to provide life-prolonging treatment.

On the surface, however, it seems, at the very least, counterintuitive to say the doctors did no "act" to disconnect the patient. They or their assistants surely had to pull out plugs, extract tubes, and deliberately cut off the flow of sustenance. Nevertheless, the Barber court managed to conclude that this fairly elaborate conduct constituted neither acts nor murder. ${ }^{90}$ Essentially, the court's reasoning went like this: The operation of the self-propelled life support devices in question was "comparable" to manually administering injections or medication. To cease manual injections or medication would merely be an omission to provide further treatment, not an act. "Hence," the court asserted, to disconnect a self-propelled device is "comparable to withholding the manually administered injection or medication."91 On the basis of this assertion, it concluded that the doctors' conduct was merely an omission to provide further treatment, not an act.

The court's logic to distinguish acts and omissions may seem a bit contrived, though it is probably no more contrived

${ }^{88}$ See Barber, 195 Cal. Rptr. at 490.

${ }^{89}$ See supra text accompanying notes 71-87.

${ }^{90}$ See Barber, 195 Cal. Rptr. at 490.

${ }^{91}$ Id.; see also Glanville Williams, Euthanasia, 41 MEDICO-LEGAL J. 14, 21 (1973), reprinted in SANDFORD H. KADISH \& STEPHEN J. SCHULHOFER, CRIMINAL LAW AND ITS PROCESSES 201 (6th ed. 1995); GlanVille Williams, TextbOOK OF CRIMINal LAW 282 (1983). 
than the act/omission dichotomy itself. ${ }^{92}$ A seemingly more serious objection to the court's logic is that it appears to reach too far: The very same reasoning that the Barber court used to exonerate the doctors would appear to be equally apt to exonerate almost anybody who might disconnect a dying patient from life support. Suppose, for example, a mere interloper entered the patient's room and cut off the machinery "just for fun," or that a covetous relative did so in order to hasten an inheritance, or to prevent its dissipation in medical bills. Should a court be required, at the trial of such a person, to treat the disconnection as an omission and to dismiss the charges on the ground that, like the doctors in Barber, the interloper or relative had no affirmative duty to provide the patient with care? It is hard to believe that a court would regard such behavior by the interloper or relative as anything but "acts," plain acts of murder.

As was explained in Airedale NHS Trust $v$. Bland, ${ }^{93}$ the interloper situation is clearly distinguishable from that of the doctors: "[W] hereas the doctor, in discontinuing life support, is

92 As should be apparent, almost any affirmative act can also be fairly readily described as an omission, and vice versa. Does, for example, a truant student affirmatively "cut classes" or merely omit to attend them? Obviously, the student does both. Examples such as these, which can be multiplied indefinitely, reveal the whole attonission distinction of the criminal law as being, in its essence, no more than a beguiling sophistry, a linguistic construct that cannot in itself carry real analytical or moral weight. Cf. Justice Scalia's analysis demolishing the similarly illusory "harm/benefit" dichotomy in the constitutional law of takings, in Lucas v. South Carolina Coastal Council, 505 U.S. 1003, 1024-25 (1992).

The really crucial distinction in the omission cases is the distinction of duty. Lethal conduct that violates a duty is (with mens rea and proximate cause) considered criminal homicide, and lethal conduct that does not violate a duty is not considered homicide. However, this distinction of duty in no way depends on the linguistic classification of act-vs.-omission. If a person violates a duty, and death results, it is homicide whether or not the violation is accomplished by an act or an omission. In "act"-homicide cases, the duty is normally a negative duty, a duty to forbear.

By contrast, in "omission"-homicide cases, the duty is conventionally described as an affirmative duty, a duty to affirmatively act. Either way, however, it is the violation of duty that is the key. If the legal duty is missing-for example, in cases of self-defense, state executions or war-lethal "acts" are no more crimes than are lethal "omissions" in the absence of legal duty. In other words, the law with respect to acts and with respect to omissions can be wholly assimilated to one another by simply recognizing the rule that "there is no crime without a duty," a rule that is just as true of act-homicides as it is of omission-homicides. When guilt or innocence is viewed as depending on whether there is breach of legal duty, rather than on linguistic classifications of conduct, the supposed analytical dichotomy between acts and omissions disappears. It is shown to be merely a distracting linguistic illusion.

"1 1 All E.R. 821 (H.L. 1993). 
simply allowing his patient to die of his pre-existing condition, the interloper is actively intervening to stop the doctor from prolonging the patient's life, and such conduct cannot possibly be categorised as an omission." 94 In other words, the interloper obstructs a flow of medical services that the patient was entitled to receive, or in any event would have received, while the doctors merely cease to provide it. Because the interloper's conduct modifies a course of events, instead of "simply allowing" events to take their course, the interloper is properly understood to have done an "act"-quite distinguishable from the mere omission of the doctors.

There is, however, a problem with drawing confident conclusions from the interloper example described in Airedale. The problem is that, as portrayed in Airedale, the interloper differs in a second (and highly prejudicial) respect from that of the patient's own doctors: The interloper had no business fiddling with the medical machinery at all. Therefore, the interloper's conduct in disconnecting the patient seems to be a purely gratuitous or selfish infliction of harm. The same could presumably also be said of the patient's covetous relative, motivated by the inheritance. It is obvious enough how these factors of gratuitousness or selfishness might tend to pump our moral intuitions, causing us to lean against exonerating the interloper or relative no matter what. However, the presence of these factors also raises at least the suspicion that the interloper/relative counterexamples are rigged. Are we actually reacting to the repellant factor of gratuitousness or selfishness, or is there really a substantive difference to be found in the distinction between $o b$ structing a flow of medical care and merely ceasing to provide one?

To test the genuineness of the Airedale distinction between obstructing life support and merely "discontinuing" it, let us suppose a hypothetical where the elements of gratuitousness and selfishness are both removed from the equation. Suppose, for example, that the life-saving machinery were disconnected, not by a mere interloper, but by somebody who was legitimately interested (albeit conflictually) in how these valuable resources were used: 
A hospital administrator, pre-occupied with costs, slips into the room of an impecunious patient and, against doctors' orders, disconnects various life-sustaining devices owned by the hospital. He does so because he is concerned that the patient is rapidly consuming various hospital resources, which neither the patient nor his estate are able to pay for. Although the hospital is contractually obligated to continue providing the devices (i.e., the case is not yet "futile"), the administrator reasons that it is economically preferable for the hospital to breach its contract and risk paying whatever damages might be assessed than to bear the certain cost of performing its contract duties to the patient.

Even though the elements of gratuitous harm and personal selfishness are now removed, the analysis should still probably be the same as that of the interloper presupposed in Airedale. ${ }^{95}$ Again, what we have is conduct to obstruct medical care, a person "actively intervening to stop the doctor from prolonging the patient's life." 96 Since the hospital had a legal duty to the patient at the time the administrator intervened, this is surely not a case of "simply allowing [the] patient to die of his pre-existing condition," 97 i.e., an omission. Rather, like the Airedale interloper, the hospital administrator has "actively intervened to stop the doctor" from providing needed care. When a person prevents another from giving life-critical assistance, knowing that its absence will mean a high risk of death, the conclusion seems inescapable that the one who prevents it is a proximate causer of death, if death in fact ensues. ${ }^{98}$ It does not exonerate the administrator that he did not personally have an affirmative duty to the patient. He had a negative duty, a duty to forbear from injuring

95 Compare Commonwealth v. Marcelli, 411 N.E.2d 270, 271 (Mass. App. Ct. 1982) (stating that "[o]ne who intentionally prevents a third person from giving to another aid necessary to prevent physical harm to him, is subject to liability for physical harm caused to the other by the absence of the aid which he prevented the third person from giving") (quoting RESTATEMENT (SECOND) OF TORTS \$ 326 (1965) with State ex rel. Martin v. Tally, 15 So. 722,739 (Ala. 1894) (stating that "[i]f the aid in homicide can be shown to have put the deceased at a disadvantage, to have deprived him of a single chance of life which but for it he would have had, he who furnishes such aid is guilty, though it cannot be known or shown that the dead man, in the absence thereof, would have availed himself of the chance").

${ }^{96}$ Airedale NHS Trust, 1 All E.R. at 868.

${ }^{97}$ Id.

${ }^{98}$ See supra note 95. 
others by obstructing the flow of essential medical care to which they were entitled. ${ }^{99}$

The analysis of the hospital administrator hypothetical may be especially pertinent to analyzing a wrongful HMO denial. The position of the errant hospital administrator is very similar to that of an HMO functionary who effects a wrongful denial of medical authorization to a patient who dies as a result. In both situations what we have is conduct to prevent a flow of lifeprolonging medical care to a person entitled to receive it-conduct that Airedale says "cannot possibly be categorised as an omission." 100 If the HMO has a duty to provide a particular treatment to a patient, the acts of HMO personnel that prevent the fulfillment of that duty would seem to be as criminally culpable as those of the hypothetical hospital administrator. Such administrative conduct constitutes affirmative acts that foreseeably and directly deprive a person of life-critical treatments to which the person is legally entitled. ${ }^{101}$

${ }^{99}$ See id. Concerning negative duties, see supra note 92.

${ }^{100}$ Airedale NHS Trust, 1 All E.R. at 868.

${ }^{101}$ Two pertinent variations on the hospital administrator hypothetical in the text are:

Case 1: A hospital administrator tells an orderly to remove a respirator that is sustaining the life of a certain elderly patient so that the device can be used to save the life of a young man who has just been admitted following a serious accident. The elderly patient dies because the respirator is removed.

Case 2: A hospital administrator is faced with an urgent need for two respirators, one to sustain the life of a certain elderly patient and one to sustain the life of a young man who has just been admitted after foolishly causing himself to be injured in a serious accident. The administrator decides to assign the hospital's sole functioning respirator to the elderly patient. The young man dies for lack of a respirator.

It seems clear enough that Case 2 presents a stronger case for exonerating the administrator than Case 1, but it is hard to say legalistically exactly why this should be so. Of course, it would put a different cast on both of these cases if (analogous to forprofit HMOs) the hospital's stockholders were economically affected by the choices made by the administrator in allocating the respirators, leading the administrator to make the selections based on what was best for them. 


\section{The Limits on the HMO's Duties to Provide Medical Care}

Even though it is an affirmative act for an HMO functionary to cause a wrongful treatment denial, ${ }^{102}$ the question of duty is still crucially relevant to the analysis of criminal liability. For unless the HMO has a legal duty to supply the treatment denied, the functionary who effects the denial does not factually "prevent" a flow to the patient of medical services that the patient was entitled to receive; ${ }^{103}$ none were flowing or promised in the first place. To take an obvious example, suppose a seriously ill patient needs life-sustaining treatment and, due to some sort of clerical mistake, she applies to the wrong HMO, one with which she has no contract. Certainly, a denial of treatment benefits by a wrong HMO should not occasion criminal liability: In such a case the HMO is merely a bystander and, at common law, a mere bystander generally has no duty at all to save others in need. ${ }^{10-1}$ Logically, too, it would seem that exactly the same reasoning ought to apply if a patient applies to her own HMO for a treatment not covered by the HMO agreement-"no duty, no guilt." 105 Accordingly, the question of criminal liability seems to turn, crucially, on the scope of the HMO's duty to provide the care that the HMO functionary refused to authorize.

The legal duties of HMOs to provide medical care are based on the agreements they make with their subscribers. The scope of the HMO's duties is presumably limitable by the terms of those agreements, and they can vary considerably in their details. ${ }^{106}$ Different agreements may have exclusions for different kinds of conditions and experimental therapies, as well as

${ }^{102}$ See discussion supra text accompanying notes 88-101.

${ }^{103}$ See supra text accompanying note 100.

${ }^{104}$ See, e.g., Albright v. State, 280 So. 2d 186, 190-91 (Ala. Crim. App. 1973) (upholding a demurrer to an indictment that failed to allege the status relationship that gave rise to a duty to act); People v. Oliver, $258 \mathrm{Cal}$. Rptr. 138, 142 (Ct. App. 1989) (noting that there is no legal duty to render aid in absence of a special relationship); Pope v. State, 396 A.2d 1054, 1064 (Md. 1979). See generally DRESSLER, supra note 1, at 86-87 (describing general rule of liability for failure to act); LAFAVE \& ScoTT, supra note 1 , at 203,211-12 (indicating there is no legal duty to aid another in peril).

Cf. supra text accompanying notes 71-87 (describing the "no duty, no guilt" analysis of Barber).

${ }^{106}$ Although it is possible that statutory or common law regulations might declare certain attempts at treatment exclusions to be void as against public policy, such limitations on HMOs' freedom of contract are beyond the scope of this article. 
differing decision procedures, payment conditions, arbitration provisions, and other variations. Moreover, an HMO's contractual duty to provide care does not necessarily run to the point of "futility," as did the doctors" duties in Barber. Instead, the HMO may describe the outer limits of its duties in less comprehensive terms, for example by committing itself only to provide those tests and treatments that are "medically necessary"107 or not "experimental." 108

To the extent that HMOs contract to assume less extensive duties to provide medical care than those imposed on physicians, they make it almost inevitable that severe disappointments will occur. The resulting discrepancies in legal duties make it almost inevitable that occasions will arise in which a patient's physician will be duty-bound to recommend or order medical treatments but the HMO will have no duty to pay for them. The tensions and dissatisfactions that will emerge from these situations should be plain.

For present purposes, however, we need not examine the variations on the HMOs' contractual duties in detail. Although contractual terms limiting HMOs' duties will present factual and interpretive questions in each particular case, their exis-

${ }^{107}$ See, e.g., Scalamandre v. Oxford Health Plans (N.Y.), Inc., 823 F. Supp. 1050, 1058 (E.D.N.Y. 1993) (emphasis added):

Further, Oxford refers to a provision in [The Handbook] entitled 'Supplemental Medical Expenses Benefits: Covered Expenses,' which reads: A Covered Expense is the lesser of the Usual Charge or the Reasonable Charge for any of the services and supplies listed below. Such services and supplies must be recommended or approved by a Doctor as medically necessary and incurred while insurance or an Extension of Benefits is in force. They must also be medically necessary, in our judgment, for the treatment of a Covered Person's Injury or Sickness for which insurance is provided under the policy.

See also Fuja v. Benefit Trust Life Ins. Co., 18 F.3d 1405 (7th Cir. 1994) (upholding HMO contract limitation to that which is "medically necessary"); Farley v. Benefit Trust Life Ins. Co., 979 F.2d 653 (8th Cir. 1992) (using "medically necessary"); Dozsa v. Crum \& Forster Ins. Co., 716 F. Supp. 131, 134 (D. N.J. 1989) (using "“reasonably necessary' for medical care"); Anderson v. HMO Nebraska, Inc., 505 N.W.2d 700, 704 (Neb. 1993) (stating that the HMO was empowered by the contract to determine "medical necessity," which included a consideration of what treatments were "most cost effective").

${ }^{108}$ See, e.g., Dozsa v. Crum \& Forster Ins. Co., 716 F. Supp. 131, 134 (D. N.J. 1989); Scalamandre, 823 F. Supp. at 1061-62 (implying that if treatment was experimental, it would not be covered under the plan). 
tence does not in any way foreclose the threshold question under discussion here, namely, whether the ordinary definitions of existing law make it a criminal act for HMO personnel to order a wrongful benefits denial knowing it will probably lead to death or serious injury. For purposes of this question it is only necessary that a judge or jury be able to find that the HMO in question had a contractual obligation to approve the treatment that was denied and that the HMO did not follow its own contractual rules, so that the denial can be considered "wrongful."

\section{MENTAL CULPABILITY}

Like other homicides, lethal administrative conduct on the part of HMO functionaries and managers is criminal only if the requisite mental culpability is present. In this section, three aspects of mental culpability will be discussed: knowledge of the risks to the patient; knowledge of the legal duty; and the problem of getting proof of the requisite mental culpability.

\section{A. Knowledge of the Risks}

The mental culpability for homicide varies with the degree of the crime charged. It ranges from the mental states of intention or purpose to cause death (typically murder), through recklessness regarding the risk of death (typically involuntary manslaughter), down to the minimum mental culpability for guilt, criminal negligence. ${ }^{109}$ "The doing of an act, or imperfect performance of a duty, toward a person who is helpless, which naturally and ordinarily leads to the death of such person, is murder, if death or grievous bodily harm is intended; and manslaughter, if the cause is negligence."110

$10 \%$ See, e.g., MODEL PENAL CODE $\$ \S 2.02 \& 210.0-.4$ (Official Draft 1962) (defining four states of culpability and requisite mental states for the commission of criminal homicide, respectively); N.Y. PENAL LAW $\$ \$ 15.05 \& 125.00-.27$ (McKinney 1998) (defining culpable mental states and the different types of homicides under New York law, respectively). See generally LAFAVE \& SCOTT, supra note 1, at 214 (describing the various mental states in defining crimes); DRESSLER, supra note 1, at 467-68 (describing general principles of degrees of mental culpability for criminal homicide). Classifications and designations of homicides vary considerably from state to state, see LAFAVE \& SCOTT, supra note 1, at 642-46, 652, 668-69. The summary in the text primarily reflects the Model Penal Code prototype.

${ }^{110}$ People v. Montecino, 152 P.2d 5, 13 (Cal. Dist. Ct. App. 1944) (quoting I WHARTON's CRIMINAL LAW 714 (12th ed. 1932)). 
Despite the strong economic incentives that HMOs have to remove net-negative subscribers from their rolls as quickly as feasible, we will pass over the possibility that these incentives might motivate treatment denials for the conscious purpose of shortening life. This does not, however, eliminate the possibility of a murder charge for an HMO denial. In general, the law treats the result of an act as "intended" if the act is done with an awareness that the result is practically certain to occur. ${ }^{111}$ This sort of "intention" might be found, for example, in a case where an HMO medical reviewer denied authorization for a lifecritical treatment with the knowledge that the patient's prognosis would be very grim without it.

Moreover, even a merely "reckless" homicide can be treated as murder if the circumstances manifest extreme indifference to the value of human life. ${ }^{112}$ Suppose, for example, an HMO manager makes a decision to deny life-critical medical care for essentially financial reasons, or on the ground that the patient's life is not simply "worth it"-due to advanced age, poor overall condition, mental infirmity, net-negative economic prognosis, or other invidious discrimination. Such a denial may very plausibly be considered to evince a sufficient indifference to the value of human life to support a charge of murder.

In addition to possible murder charges, lesser degrees of homicide might apply to deaths that are caused with lesser

111 See, e.g., People v. Stanciel, 606 N.E.2d 1201, 1210 (IIl. 1992) (stating that to show intent to commit murder "it is sufficient to show that the defendants voluntarily and willfully committed an act, the natural tendency of which is to destroy another's life. Intent may be inferred from the character of defendant's acts as well as the circumstances surrounding the commission of the offense" (citation omitted)); see also MODEL PENAL CODE $\S \S 2.02(2)(b)(i i) \& 210.2(1)(a)$ (Official Draft 1962) (discussing "knowingly" committed culpable conduct and indicating that murder is committed either purposely or knowingly, respectively). See generally DRESSLER, supra note 1, at 105-06 (defining "intentionally"); LAFAVE \& SCOTT, supra note 1, at 216-18 (describing "intent" and "knowledge" as related to crimes).

112 See, e.g., People v. Burden, 140 Cal. Rptr. 282, 291-92 (Ct. App. 1977) (affirming conviction for second-degree murder for neglect of child whose death was caused by malnutrition and dehydration); People v. Register, 457 N.E.2d 704 (N.Y. 1983) (finding defendant acted with "depraved indifference to human life" by firing a gun in a crowded bar and by firing at an unknown person for no explained reason); Commonwealth v. Malone, 47 A.2d 445 ( $\mathrm{Pa}$. 1946) (upholding murder conviction for defendant who killed another while playing Russian poker due to his wicked disposition); see also Pallis y. State, 26 So. 2d 339 (Ala. 1899) (stating that "if the . . . neglect is of a dangerous kind, it is murder"); MODEL PENAL CODE $\$ 210.2(1)$ (B) (Offcial Draft 1962) (enumerating the action and situations where the actor will be presumed to have acted recklessly and indifferently). 
mental culpabilities. For example, a denial of benefits that is ordered with a mental state of "recklessness" should attract at least a charge of involuntary manslaughter. ${ }^{113}$ The influential Model Penal Code defines recklessness as occurring when a person "consciously disregards a substantial and unjustifiable risk" if the disregard "involves a gross deviation from the standard of conduct that a law-abiding person would observe" under the circumstances. ${ }^{14}$ It defines the still lesser culpability of criminal negligence as arising when a person "should be aware of a substantial and unjustifiable risk" and yet acts in disregard of that risk. ${ }^{115}$ When a medical reviewer who ought to know the risks decides to cause a denial of essential medical treatment, and the denial triggers a patient's death, there would seem to be at least a case of negligence or recklessness and, therefore, a basis for charging negligent homicide or involuntary manslaughter. If the person who causes the denial does so with almost certain knowledge that it will lead to the patient's death, it would seem to be one of the degrees of murder.

\section{B. Knowledge of the Duty}

Although knowledge or foreseeability that an action will have potentially lethal consequences is a standard element of criminal liability for death, it is not so clear that the HMO functionary need know the nature or exact scope of the HMO's legal duty. In the typical case, of course, the HMO medical reviewer almost certainly ought to know at least the general tenor of the HMO's duty to the patient; before presuming to order a denial of treatment, she should have at a minimum made herself aware of the terms of the subscriber's agreement, the patient's diagnosis, the treatment requested, and whether the HMO's protocols describe such treatments as indicated for persons with

${ }^{113}$ See, e.g., MODEL PENAL CODE $\$ 210.3(1)$ (a) (Official Draft 1962) (stating that a criminal homicide is manslaughter if committed recklessly); N.Y. PENAL LAW $\$ 125.15$ (1) (McKinney 1998) (defining second degree manslaughter).

${ }^{114} \$ 2.02(2)(c)$ (Official Draft 1962); cf. Commonwealth v. Welansky, 55 N.E.2d 902 (Mass. 1944) (holding that reckless conduct is an act or an omission whereby the act or omission will lead to a high degree of likelihood that harm will result to another).

${ }^{115}$ MODEL PENAL CODE $\$ 2.02(2)$ (d) (Official Draft 1962); cf. State v. Williams, 484 P.2d 1167 (Wash. Ct. App. 1971) (holding that regardless of the individual's mental state, if the conduct does not measure up to conduct required of a reasonable person, the individual is guilty of negligence). 
the patient's condition. With this information at hand, she should be able to infer the HMO's probable duties, as well.

At any rate, the preeminent case for an HMO-homicide prosecution would be one in which the HMO's decision-makers were consciously aware that a treatment denial would not likely be upheld in court if the HMO were (or could be ${ }^{116}$ ) sued, but they went ahead and ordered the denial anyway-perhaps figuring that a chance of being forced to pay civil damages in the future was a financially better risk than the certainty of paying right away. ${ }^{117}$

Suppose, however, that an HMO medical reviewer was truly under the impression that the HMO had no legal duty to authorize treatment in the particular case. Suppose, for example, the reviewer orders a denial of medical treatment while fully aware of the mortal risk that denial poses to the patient, but she honestly, albeit erroneously, concludes that the HMO's contract does not cover the requested treatment because it is not, in her judgment, "medically necessary." If a judge or jury later concludes that the treatment was "medically necessary," based on a trial with expert testimony, is the HMO reviewer guilty of criminal homicide for the death that ensued, or does she have an excuse because it was her honest judgment that the treatment was not necessary? ${ }^{118}$

On one hand, this misconception of the HMO's legal duty would not appear to be a simple case of "mistake of fact," where an honest error or ignorance serves as a defense because the error negates the mental state that is an essential element of

${ }^{116}$ Bear in mind, the Federal ERISA severely limits private lawsuits in many instances. See 29 U.S.C. § 1144(a) (1994).

${ }^{117}$ See infra Part IV.C (including a discussion of obtaining proof of such a conscious awareness).

${ }^{118}$ Lest one think this situation is unrealistic, consider: "Last year a Medicare carrier in the St. Paul area rejected a claim-three times-as 'medically unnecessary' even though the patient died within an hour of arriving at the hospital." Daniel Eisenberg, Critical Condition, TIME, Jan. 31, 2000, at 52, 54. Such a thing can easily happen. Suppose, for example, a terminally ill patient decides she wants to die at home"there is nothing more they can do." A few days after going home she has a severe respiratory crisis and her distraught family, in panic, call an ambulance. Is an expensive trip back to the hospital "medically necessary," even though it would, at best, only let her live a few more days, until some later crisis finally brings the end? More generally, a cost-conscious HMO might ask, when is it ever "medically necessary" to perform extensive therapy, other than palliative, on people lingering at the edge of death? These end-of-life situations pose legal questions of duty that stubbornly remain even after all of the medical facts are known. 
the crime in question. ${ }^{119}$ On the contrary, the reviewer fully knew the factual character of what she was doing. She knew that her action was almost certain to have fatal consequences (the mental element of criminal homicide) but, because she misinterpreted or misapplied the HMO contract, she thought that such lethal behavior was, on her part, legally permissible.

The meager law available from the criminal omissions context also does not well support the idea that ignorance of a legal duty is an exonerating excuse when a person breaches the duty and another's death foreseeably results. ${ }^{120}$ For example, the avaricious uncle who allowed his nephew to drown ${ }^{121}$ would probably not be allowed to claim he did not know that guardianship carried with it a duty to save his nephew from accidental death. ${ }^{122}$ Likewise, the hospital administrator who, pre-occupied with costs, disconnected a patient from life support ${ }^{123}$ should presumably not be heard to claim that he mistakenly thought that, like a hotel, the hospital had no legal duty to accommodate people who could no longer pay their bills. Perhaps such claims of ignorance would not be regarded as reasonable mistakes in any event, but the point here is that, reasonable or not, there seems to be no legal basis for thinking they even would be heard at all. In sum, the existing criminal law seems, if anything, to weigh against giving a legal excuse where the HMO functionary errs in interpreting the legal duty of the HMO.

${ }^{119}$ See LAFAVE \& SCOTT, supra note 1, at 405-07 (discussing how ignorance or mistake as a matter of fact or law is a defense if it negates a mental state required to establish the crime); see also MODEL PENAL CODE \& 2.04(1)(a) (Official Draft 1962) (stating that ignorance or mistake is a defense if it "negatives the purpose, knowledge, belief, recklessness or negligence required to establish a material element of the offense"). Knowledge of legal duty is not, however, ordinarily an element of the crimes of homicide. See, e.g., MODEL PENAL CODE $\$ \S 210.1-.4$ (Official Draft 1962). Furthermore, "a reasonable belief on the part of the defendant that the law is such that his conduct does not constitute an offense. . .[n]ormally. . .is irrelevant. ..." MODEL PENAL CODE, $\$ 2.04 \mathrm{cmt} .3$ (1985).

${ }^{120}$ See LAFAVE \& SCOTT, supra note 1, at 207-08 (discussing whether liability may be imposed when defendant is unaware of the facts giving rise to the duty). But compare the narrow exception recognized in Lambert v. California, 355 U.S. 225 (1957) (holding that ignorance of a legal duty could be a constitutional defense to an omission-offense if nothing in the circumstances gave any warning or notice that any such duty might exist at all).

121 See supra text accompanying notes 6-7.

122 See LAFAVE \& SCOTT, supra note 1, at 208.

${ }^{123}$ See supra text accompanying notes $95-101$. 
On the other hand, it would be very harsh if people who are required to make life-or-death decisions in their daily work were held to do so at entirely their own peril in the event they were to misapply a contract. It would be not only harsh, but it would be a bad policy for the public, as well. After all, we should not as a society want to drive reasonable and conscientious people out of the HMO business entirely. That is, however, exactly what we ought to expect to happen if errors in medical judgment, or medico-economic judgment, were to put the decision-makers in personal peril of prosecution.

When lethal administrative errors occur in the HMO approval process, it therefore seems to make sense to allow an accommodation for cases of good faith mistake, similar to that allowed in cases of mistaken self-defense. Under the law of self-defense, it can be legal to kill a perfectly innocent person who is posing no menace to anyone ${ }^{124}$ provided that the killer actually believes ${ }^{125}$ that the use of deadly force is necessary for self-protection from serious harm or death. ${ }^{126}$ That is, the law leaves a margin of safety to allow people to act in borderline cases.

Similarly, whether or not a treatment for a particular condition is "medically necessary" is a class of judgment that

124 See, e.g., People v. Adams, 491 N.E.2d 54 (IIl. App. Ct. 1972) (finding defendant not guilty of involuntary manslaughter when a bullet he fired passed through the body of an attacker and killed an innocent victim). See generally LAFAVE \& SCOTT, supra note 1, at 457-58 (indicating that self-defense requires the defendant to honestly believe in the necessity of using force, even if he is mistaken in that belief).

${ }^{125}$ See MODEL PENAL CODE $\$ 3.04$ (b) (Official Draft 1962) (deadly force not justifiable unless actor believes such force is necessary for self-protection). Most say the defendant must also reasonably believe. See, e.g., N.Y. PENAL LAW $\$ 35.15(2)$ (McKinney 1998) (requiring reasonable belief in a reasonable necessity of deadly force); see also United States v. Peterson, 483 F.2d 1222 (D.C. Cir. 1973) (stating rule requiring reasonable belief of imminent peril); People v. Goetz, 497 N.E.2d 41, 50-51 (N.Y. 1986) (concluding that an objective standard should be used to determine if the actor reasonably believed use of deadly force was necessary). See genter. ally LAFAVE \& SCOTT, supra note 1, at $457-58$ (discussing the requirement that the defendant's belief in the necessity of using force be reasonable and honest).

${ }^{126}$ See LAFAVE \& SCOTT, supra note 1, at 457-58. There may also be other conditions attached to the defense, such as the unavailability of a safe retreat or that the killer not be the original aggressor, but none of these conditions changes the fact that the law of self-defense justifies the killing of innocent people under certain circumstances, one of which is a (reasonable) belief in the necessity. See generally id. at 459-61 (noting what constitutes lawful and unlawful force and the necessity to retreat). 
surely has many borderline cases, where the conclusions and judgments of reasonable experts may differ. Surely, too, there are many cases when the medical necessity is not borderline, situations in which it is almost certain that certain wellestablished treatments will help and, without them, the patient will die or grievously suffer. In the borderline situations, the case for allowing a legal excuse for wrongful denials seems strong. In the non-borderline situations, however, where the reasonable persons in the field would find the "medical necessity" to be clear, the matter is entirely different; there is no more warrant for excusing a lethal "error of judgment" in such cases than there is to excuse the lethal error in judgment of a truck driver in traffic who purposely steers onto a crowded sidewalk to avoid being late. ${ }^{127}$ Once a jury finds that reasonable people with suitable educational background and training could not differ on medical necessity, conviction would seem proper as a matter of course.

\section{Getting Proof of Mental Culpability}

The decisions of HMOs in individual cases and the policies and directions that guide those decisions are normally made internally; the elements that go into these decisions, policies and direction, be they proper or improper-culpable or not-lie largely outside the ken of external observers. Nevertheless, in prosecutions of lower level medical reviewers and similar personnel, proof of the crucial mental elements of criminal liability - such as knowledge of the deadly risk of a denial-should pose no special prosecutorial difficulties. The accused could hardly deny having had knowledge of the key facts that show awareness of the risk: the patient's condition and prognosis, the recommendations of the treating physician, the HMO's internal guidelines, and customary medical practices. If a medical reviewer were to maintain that she withheld medical treatment without such knowledge, it would be tantamount to admitting extreme recklessness. Getting proof of the managerial direction and mental culpabilities of people higher up in the organization is more intricate, but essentially the task is the same as that of

${ }^{127}$ See People v. Gomez, 478 N.E.2d 759 (N.Y. 1985) (affirming defendant's conviction for murder based on an objective assessment of the degree of risk presented when he erroneously drove car on sidewalk killing two children). 
obtaining mental-state evidence in any case of organizationbased criminality.

Suppose, for example, a prosecutor is looking for evidence to show that an HMO's management has deliberately put policies into place to cause time lags in the approval process for certain tests and treatments-with the foreseeable effect that patients having certain conditions and ailments would often not get approvals for treatment in time to make a life-saving difference. Remember that a relatively short delay of treatment can be enough to shorten a life. ${ }^{128}$ To obtain evidence of deliberate delay policies, a prosecutor could first bring in the medical reviewers who were immediately and visibly responsible for delaying or denying the authorization of life-critical treatments in one or more cases. The legal accusations and personal risk of conviction could be explained, along with the advantages of cooperating. Specifically, the prosecutor could request that, in exchange for leniency or immunity, these lower-level functionaries provide testimony with respect to the internal policies of their company, instructions received from their superiors, the performance criteria by which employees are judged, the patterns of approval and denial fostered among the medical review staff, and the like.

By working "up the ladder" with successive interviews of this sort, a resourceful and motivated prosecution could take the case right up to the high-level locus of actual policy formation. In fact, getting the needed evidence of managerial-level culpability may be even easier in the case of HMOs than in other multiparty criminal cases because the lower-level personnel involved are likely to be less nonchalant about the prospect of imprisonment than more traditional criminal actors; they may, that is, be relatively more amenable to cooperating with the government. ${ }^{129}$

\footnotetext{
${ }^{128}$ See Ware, Jr. et al., supra note 22, at 1043-44 (discussing the effect of time on health).

${ }^{129}$ For my own part, it should be said, I do not approve of these essentially extortionate governmental tactics for obtaining evidence, and I do not personally consider the evidence obtained by them to be especially reliable. Accord United States v. Singleton, 144 F.3d 1343 (10th Cir. 1998) (holding that the use of such techniques violates federal laws against bribing witnesses), rev'd, United States v. Singleton, 165 F.3d 1297 (10th Cir. 1999). However, the use of investigative duress to collect evidence is apparently commonplace, and most American courts, including the U.S. Supreme Court, apparently regard such governmental behavior as acceptable. See, e.g., United States v. Singleton, 165 F.3d 1297 (10th Cir. 1999), cert. de-
} 


\section{POSTSCRIPT}

When people do things that they know are almost certain to have lethal consequences, and death results, criminal prosecution for homicide is normally called for. The existing criminal law provides no obvious reason why there should be an exception for actions by HMO functionaries who prevent their companies from performing their legal duties to authorize and pay for critical medical care. Under the law's prevailing categories and definitions, prosecutions of HMO personnel for wrongful treatment denials appears to be logically indicated in cases where death or serious medical injury was foreseeable, and death actually results. To prosecute in such cases would be a straightforward application of the principle that, when death is foreseeable, lethal behavior is a crime. The fact that the lethal behavior may be a "rational" response to pressing economic forces would not, under ordinary criminal law, constitute an excuse or defense.

However, the economic pressures that bear on HMOs and their managements are not entirely an unintended consequence of the HMO structure or unanticipated accidents that no one could foresee, nor do they work in isolation on the HMO industry. The view is apparently held by many that fewer of our resources should go to medical treatments, so that more will be left over for other things. ${ }^{130}$ In any case, the economic pressures on HMOs do not arise ex nihilo. Rather, they are the manifestations of values and priorities that are exerted by society as a whole. The HMO industry only happens to be the locus where

nied, 527 U.S. 1024 (1999); cf. Dodd v. State, 993 P.2d 778 (Okla. Crim. App. 2000) (adopting discovery procedures to assure full disclosure when jailhouse informants are used as witnesses). See Frank O. Bowman, III, Departing is Such Sweet Sorrow: A Year of Judicial Revolt on "Substantial Assistance" Departures Follows a Decade of Prosecutorial Indiscipline, 24 STETSON L. REv. 7, 64 (1999). At least it is a better way to obtain evidence than the use of physical torture, which the Supreme Court has also recently let stand. See People v. Hanna, 567 N.W.2d 12 (Mich. App. 1997), cert. denied, Hanna v. Michigan, 120 S. Ct. 970 (2000) (upholding infliction of temporarily incapacitating pain in order to permit withdrawal of blood sample).

${ }^{130}$ As one commentator stated this point, somewhat disparagingly, "if Granny were dead then Johnny could go to college." Nancy W. Dickey, Euthanasia: A Concept Whose Time Has Come? 8 IssuEs IN LAW \& MED. 521 (Mar. 22, 1993). Alternatively, one could say, "if Granny were dead, then 10 very sick children, currently uninsured, could receive treatments that would save their lives." A third option might be: "if Granny were dead, then her health insurance company would have higher earnings-per-share." These issues are not simple. 
these pressures have a particularly visible impact. If HMO managers were in fact never influenced by the economic pressures they feel to contain the costs of medical treatments, if they never said "no" to the less promising therapies in less salvageable cases, they would not be doing the job that society has arguably charged them with doing.

In short, by allowing and even encouraging the delivery of medical services via the modern $\mathrm{HMO}$ /managed care format, society may be saying that it wants its medical care to be provided and financed under conditions that cannot possibly pay the cost of saving every life from avoidable foreshortening. If so, then it is society in aggregate which has decided that some "life-saving" must be foregone, that some lives are simply not worth the cost, and that, in consequence, lethal treatment decisions must sometimes be made. The people on the front lines of these fatal decisions are, in the final analysis, only doing the bidding of others.

Oliver Wendell Holmes once wrote: "The life of the law has not been logic: it has been experience." 131 In other words, if the application of legal rules is not "experienced" as being right, if legal outcomes do not "feel" right when put into practice, then the logic must yield to the experiences that contradict it. If the idea of homicide prosecutions for HMO managers seems repellant, even when they appear to be logically indicated by the existing categories of the law, then something must be wrong with the law. There must be something additional and decisive in the mix of considerations that affects the way that we "experience" such results.

In the case of homicide and HMOs, the most obvious "additional" factors are the considerations of social position and distinction, which can subtly enter human moral calculus. Criminal sanctions in this country are not primarily aimed at people like HMO managers and administrative personnel, but are mostly intended for a very different segment of society. ${ }^{132}$

131 OLIVER WENDELl HOLMES, THE COMMON LAW 1 (1923).

${ }^{132}$ For example, it has been pointed out that approximately $70-75 \%$ of the people locked away in the New York State's prison system come from just seven neighborhoods in New York City-among the poorest in the state. See Alexandra Marks, N.Y. Prison Religion Program Helps Turn Lives Around, ChristIAN SCI. MONITOR, Mar. 11, 1997, at 1; Susan S. Lang, Help For Neighborhoods, CHILDREN TODAY, Dec. 22, 1993, at 16 (discussing how neighborhood alliances may be a solution to problems in the poorest areas of New York); Francis X. Clines, Ex-Inmates 
As long as the punishments for homicide are limited to the "kinds" of conduct and people to which they are usually applied, the rest of us can live tolerably with the deliberate inflictions of human suffering that their application entails. When it is suggested, however, that these punishments be applied more evenly, extending also to the lethal activity of classes that the legislator may not have envisioned, we are tempted to suspect that the law's logic has gone awry. We are put on the alert to find ways to make exceptions.

Perhaps, however, this particular dissonance between experience and law goes deeper, lying beyond the reach of resolution by mere exceptions. Perhaps, instead, it is that the purposeful infliction of human suffering is itself a morally dubious way to deal with social problems, and only when we contemplate extending it beyond the usual targets do we truly comprehend its horror. 